\title{
Mondini and the Dysplastic Lateral Semi-Circular Canal
}

\begin{tabular}{|l|l|l|}
\hline P.D. & Peter D. & Phelps \\
\hline
\end{tabular}

London, UK

Peter D. Phelps, Gray's Inn Road, London, WC1X 8DA (UK)

Carlo Mondini in 1791 made a thorough dissection of the petrous temporal bones of an 8-yearold boy born deaf. The clear and precise anatomical description was accompanied by nine accurate line drawings of the dissections [1]. Mondini was well aware of the normal anatomy of the inner ear and described the semi-circular canals of his patient as being normal, the vestibule enlarged, the vestibular aqueduct greatly enlarged (described as ' 7 lines wide' which is approximately $15 \mathrm{~mm}$ ) and the cochlea extremely deformed: 'according to its nature the cochlea completes in its ascent two and a half turns of a spiral but in our born deaf boy it only completed one and a half since the apical turn was missing and it ended in a cavity...'[1].

As this description is so precise there would seem to be a strong argument for limiting the term 'Mondini dysplasia' to this particular deformity. Unfortunately, since Schuknecht [2] expanded the term to include a simple sac cochlea and 'Mondini dysplasia of the vestibular system' with enlarged semi circular canals, 'Mondini dysplasia' has become, especially in the USA, an umbrella term used to describe virtually any congenital malformation of the osseous labyrinth that is detected on radiographic examination [3]. This is most unfortunate, in my opinion, and has resulted in reports such as that by Komune et al. [4] in a recent edition of ORL. These authors describe a patient with normal cochleae but dilated dysplastic lateral semi-circular canals incompletely separated from the vestibule. Not only does this case bear no relation to Mondini's original description, but the anomaly is the commonest congenital aberration of the bony labyrinth and is frequently associated with normal cochlear function. I described this anomaly in 25 cases, 20 years ago [5] and our recent book [6] shows an illustration entirely similar to the one in the work by Komune et al. [4]. We would also disagree that a true Mondini deformity carries a risk of cerebrospinal fluid fistula through the deformed labyrinth and have described recently 20 patients with a true Mondini deformity or more severe dysplasia of the cochlea in 32 ears. A fistula, usually manifest by a recurrent meningitis and confirmed at surgery or post mortem, occurred in 5 of the severely dysplastic ears but not with the true Mondini deformity [7].

I believe therefore that the term 'Mondini dysplasia' has been so abused as to lose all useful meaning and should no longer be quoted but rather a complete description of the deformity given based on the CT appearances.

References

Mondini C: Anatomica surdi nati sectio. De Bononiensi scientarum et atrium institute at-que academia commentarii. Bononiae 1791;7: 419-431.

Schuknecht HF: Mondini dysplasia. Ann Otol RhinolLaryngol 1980;89(suppl 65):l-23. Jackler RK, Luxford WM, House WF: Congenital malformations of the inner ear: A classification based 
on embryogenesis. Laryngoscope 1987;97(suppl40):2-14. Komune S, Nogami K, Inou H, Uemura T: Bilateral Mondini dysplasia with normal hearing. ORL 1993;55:143-146. Phelps PD: Congenital lesions of the inner ear, demonstrated by tomography. Arch Otolaryn-gol 1974;100:11-18.

Phelps PD, Lloyd GAS: Diagnostic Imaging of the Ear. London Springer, 1990, p 56. Phelps PD, King A, Michaels L: Cochlear dysplasia and meningitis. Am J Otol, in press.

(C) 1994 S. K.arger AG, Basel

0301-1569/94/0562-0116

$\$ 5.00 / 0$ 